DOI 10.37882/2223-2982.2021.02-2.31

\title{
ИСПОЛЬЗОВАНИЕ ВИДЕОМАТЕРИАЛОВ В ПРОЦЕССЕ ГЕЙМИФИКАЦИИ ПРИ ОБУЧЕНИИ РУССКОМУ ЯЗЫКУ СТУДЕНТОВ-МЕДИКОВ
}

\section{USE OF VIDEO MATERIALS IN THE PROCESS OF GAMIFICATION IN TEACHING RUSSIAN TO MEDICAL STUDENTS \\ I. Telezhko \\ M. Yakhno}

Summary: This article deals with the use of video materials in the Internet environment for teaching Russian for special purposes to foreign medical students in the process of gamification. The developed system of tasks recreates conditions of real communication between doctor and patient, which allows to develop professional communication skills.

The proposed material was prepared on the basis of the experience of working with students studying Russian at the Medical Institute of RUDN in classes in scientific style. Promotes communication skills in the professional macrosphere as well as motivations.

Keywords: russian as foreign, professionally oriented communication, gamification, professional sphere of communication, Internet resources, educational Internet environment, professional sphere of communication of physicians, video materials.

\section{Введение}

$\mathrm{O}$ дной из целей обучения студентов из зарубежных стран русскому языку как иностранному в российском неязыковом вузе является формирование у обучающихся (в нашем случае, студентов-медиков) профессионально-коммуникативной компетенции, что предполагает наличие знания речевого поведения и сформированного умения общения в социально-профессиональной макросфере.

На практических занятиях по научному стилю преподаватель сталкивается со следующими трудностями: у большинства учащихся отсутствуют системные знания в области языка, сформированные умения позволяющие врачу поддерживать и направлять диалог с больным. Перед преподавателем возникает проблема мотивации студентов к изучению языка. Мотивация студентов к овладению иностранным языком завит от технологий и методов, которые использует преподаватель в процессе обучения языку.

В настоящее время в образовательном процессе всё чаще стал употребляться термин «геймификация» -
Тележко Ирина Владиленовна

к.n.н., дочент, Российский университет дружбы народов

(2. Москва)

Irina-Telezhko@mail.ru

яхно Мария Дмитриевна

старший преподаватель, Российский университет

дружбы народов (2. Москва)

mariayahno@mail.ru

Аннотация: В данной статье рассматриваются примеры применения видеоматериалов, функционирующих в интернет-среде при обучении русскому языку в специальных целях иностранных студентов-медиков в процессе геймификации. Разработанная система заданий воссоздаёт условия реального общения врача и пациента, что позволяет развить навыки профессиональной коммуникации.

Предложенный материал подготовлен на основе опыта работы со студентами, обучающимися русскому языку в Медицинском институте РудН на занятиях по научному стилю. Материал способствует формированию умений общения в профессиональной макросфере, а также повышению мотивации.

Ключевые слова: русский язык как иностранный, профессионально ориентированная коммуникация, геймификация, профессиональная сфера общения, интернет-ресурсы, образовательная интернет-среда, профессиональная сфера общения медиков, видеоматериалы.

«внедрение игровых технологий в неигровые процессы, в том числе в образование» [8: 15]. Геймификация коренным образом отличается от известных ранее образовательных игровых форм. Суть этого отличия заключается в том, что реальность остается реальностью, не превращаясь в игру, а игровые установки вводятся в систему операций субъекта с этой реальностью [9]. Использование геймификации предполагает максимальную визуализацию учебного материала.

Видео является эффективным средством аудиовизуальной наглядности. Данное положение подтверждено психолого-педагогическими исследованиями. Учёныеметодисты отмечают, что видео как средство обучения соответствует физиологии человека: по данным ЮНЕСКО видео позволяет оставить в памяти обучаемого (через 2 недели после просмотра) как минимум половину всей информации, в то время как для текстового источника этот показатель составляет лишь 10\% [2: 92]. Так исследователь Н.Н. Толстова указывает, что при использовании видео в дидактических целях, качество обучения повышается благодаря тому, что зрительные образы окружающей действительности в видеоформате способствуют расширению объема усваиваемого учебного материала, 
а также снижению утомляемости. Кроме того, «развиваются два вида мотивации: самостоятельная мотивация, когда видео интересно само по себе, и мотивация, которая достигается тем, что учащемуся будет показано, что он может понять язык, который изучает. Это приносит удовлетворение, придает веры в свои силы, вызывает желание совершенствовать знания» [6: 495].

Видеоматериалы, используемые в процессе обучения, понимаются как один из видов технических средств обучения, обеспечивающий функцию передачи информации, а также получения обратной связи в процессе её восприятия и усвоения с целью последующего развития у учащихся тех или иных навыков и компетенций.

В работах методистов указаны требования к видеоматериалу: видеоматериал должен содержать языковой материал, соответствующий учебным целям, продолжительностью не более 5 минут; при выборе видеоматериала следует учитывать возраст, уровень владения языком, а также цели изучения языка и потребности обучаемых; должен иметь сюжет и законченность; он должен быть интересным и достоверным $[1 ; 5 ; 6]$.

Наиболее важной в методическом плане является следующая классификация видеоматериалов:

- специально предназначенные для обучения иностранному языку;

- предназначенные для носителей языка или аутентичные, включая художественные фильмы и прямую трансляцию телепрограмм в эфир;

- разработанные самими преподавателями и обучающимися.

В данной статье мы рассматриваем примеры использования аутентичных видеоматериалов, представленных в интернет-среде при обучении языку специальности, так как они позволяют студентам овладеть необходимыми лексическими единицами, усвоить речевое поведение специалистов-медиков и таким образом приобщиться к естественной профессионально-ориентированной языковой среде, а также видео, разработанные самими учащимися в процессе геймификации.

В интернете размещены множество видеороликов, в которых представлены предметы, действия или характеристики по медицинской тематике. Представляем игру «На приёме у стоматолога» с использованием видео (https://www.youtube.com/watch?v=-t8lhy_dqNU) как деловую игру, суть которой выражается в выработке стратегии и тактики профессионального общения [3: 220]. Подобные коммуникативные акты являются для студентов основными для прохождения клинической практики.

На экране представлена коммуникативная ситуация врач - пациент (Рис.1).

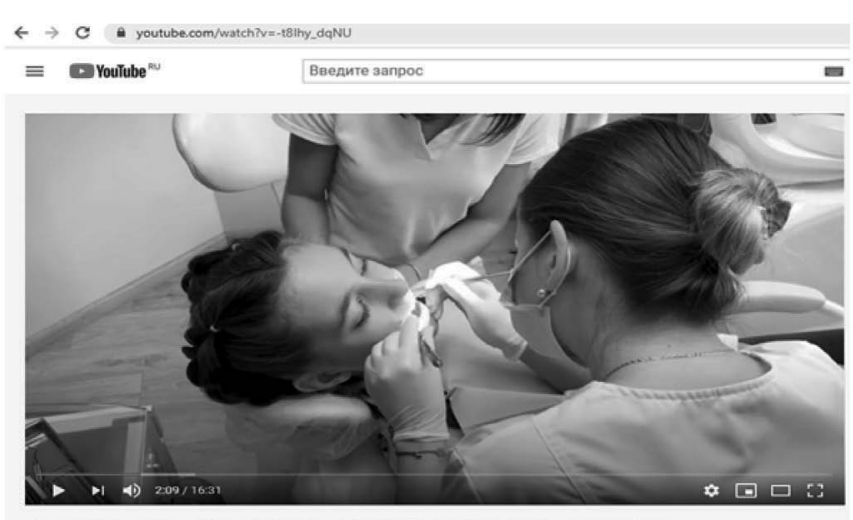

НА ПРИЕМЕ У ВРАЧА СТОМАТОЛОГА | ЛЕЧЕНИЕ | ДОКТОР | КАТЯ СЛИВИНСКАЯ

Рис.1. «В кабинете у стоматолога»

Демонстрация любого видеоматериала методисты традиционно разделяют на три этапа: подготовительный, демонстрационный и последемонстрационный.

\section{I. Подготовительный (pre-viewing)}

Цели этапа: 1. мотивировать обучающихся, настроить их на выполнение задания, сделав активными участниками игры; 2. снять возможные трудности восприятия текста и подготовить к успешному выполнению задания.

На подготовительном этапе студенты повторяют речевые формулы и лексику по заданной теме. На карточках или на доске записаны слова и выражения: войти, пройти, садиться в кресло, открыть рот, не закрывать рот, сидеть спокойно, не мешать работать, закрыть рот, сделать рентген, встать, идти в рентген кабинет.

Целесообразно выполнить подготовительное грамматическое упражнение на отработку форм повелительного наклонения, так как будущий врач-стоматолог будет общаться с пациентом в форме повелительного наклонения. Например: попросите больного выполнить следующие действия: повторить рентген, сплюнуть, отдохнуть, прикусить бумажку, пожевать.

\section{II. Восприятие фильма или Аемонстрашионный этап (while viewing).}

Цель этапа: обеспечить дальнейшее развитие языковой, речевой компетенций учащихся с учётом их реальных возможностей иноязычного общения.

На этом этапе используются задания, направленные на поиск, вычленение, фиксирование, трансформацию определенного языкового материала: лексики, грамматики, фонетики. В данном случае не столько формулировка задания, сколько содержание упражнения обеспечивает ту или иную степень эффективности и 
оправданности выполнения задания.

Во время восприятия видеоматериала на демонстрационном этапе студенты-зрители принимают активное участие. Программа управления восприятием фильма преподавателем может быть предложена в форме составления списка опорных лексических единиц. Вместе с тем студенты могут отметить звучащие в видеофильме новые для них модели речевого поведения русскоязычных специалистов.

После просмотра видео студентам предлагаются следующие задания:

- разыграйте диалог «На приёме у стоматолога» на основе просмотренного видео (этот вид задания позволит приблизиться к научному стилю общения принятого в русскоязычной профессиональной сфере общения медиков;

- выступите в роли актёров и озвучьте видео, включенного без звука, (на данном этапе используется методический метод «немое кино». Работа выполняется в парах с распределением ролей: больной и врач в устной форме или преподаватель может попросить в письменной форме записать диалог врача-стоматолога и пациента).

Усвоение вербального и невербального поведения врача и пациента с использованием видеоматериалов на основе речевых образцов, их тренировка в упражнениях расширяет языковой потенциал для перехода с репродуктивного уровня на более высокий уровень владения профессиональными коммуникативными умениями. Следует отметить, что за каждое выполненное игровое задание обучающимся начисляются баллы.

\section{III. Зак^ючительный этап (последемонстрашионный)}

Цель этапа: использовать исходный видеоматериал в качестве основы и опоры для развития продуктивных умений в устной или письменной речи.

На данном этапе проверяется эффективность использования в процессе просмотра видео ориентиров, предложенных на подготовительном этапе восприятия, и использованных в фильме языковых и речевых средств. Видео является средством оценки пройденного материала.

Для этого используется модель «Мобильное видео». Мобильное видео - созданное без тщательнейшей подготовки аудио-визуальное произведение, в котором студенты могут рассказывать о заинтересовавших их явлениях действительности, а также о явлениях и предметах, изучаемых непосредственно на уроках русского языка как иностранного [5]. Например, будущим стоматологам предлагается снять видео по следующим коммуникатив- ным ситуациям: «У меня заболел зуб»; «В рентгенкабинете»; «В стоматологической поликлинике»; «На приёме у протезиста» и др.

Созданные видеоматериалы должны быть проанализированы преподавателем по следующим показателям:

- соответствие диалога заданной коммуникативной ситуации;

- полнота раскрытия проблематики профессиональной ситуации;

- умение вести диалог: поддержание лидирующей позиции в диалоге.

Что касается лингвистической характеристики диалога, здесь следует обращать внимание на использование формул речевого этикета, объём диалога, преобладание речевых стереотипов.

Представляем алгоритм работы по созданию видеодиалога: «У стоматолога». После изучения необходимой лексики и грамматических конструкций во время основного урока (просмотр видео, предложенного преподавателем) на заключительном этапе проводится подготовительный этап работы по созданию видео в качестве домашнего задания.

Задание: Сделайте запись видео на мобильный телефон. Тема видео - диалог-осмотр врача-стоматолога с пациентом.

После этого преподаватель даёт инструкцию по созданию видео:

1. Продумайте и составьте сценарий видео-диалога. В сценарии должны быть следующие тематические разделы:

- паспортные данные больного;

- жалобы;

- характера боли;

- время появления симптома;

- осмотр;

- д дигноз и дальнейшая подготовка к процедуре.

На данном этапе формируются навыки письма и чтения, потому что студенту предлагается прочитать инструкцию для создания сценария, и после прочтения студенты пишут сценарий видео.

2. Демонстрация сценария преподавателю. Преподаватель просматривает сценарий, написанный студентом, комментирую грамматические ошибки.

3. Создание видео. Студенты в парах снимают видео по сценарию (внеаудиторная работа).

4. Демонстрация видео. Этот этап проходит на сле- 
дующем уроке. После просмотра видео студентам необходимо ответить на вопросы преподавателя:

Задание 1. Ответьте на вопросы:

- Что вам понравилось / не понравилось?

- Какие слова, которые мы учили на прошлом уроке, были использованы в видео?

- Какие грамматические ошибки были сделаны?

- Были ли соблюдены правила профессионального этикета?

Задание 2. Посмотрите видео еще раз и ответьте на следующие вопросы:

- Сколько лет пациенту?

- На что пациент жалуется?

- Как давно он был у стоматолога?

- Куда отдаёт боль?

- Как давно он чувствует боль?

- Какие процедуры проводит врач-стоматолог?
Созданные студентами видео могут быть загружены на любой площадке социальной сети и использоваться в дальнейшем как аудио-визуальный дидактический материал. В результате создания тематического видео формируются умения устной речи (монолог, диалог); совершенствуются навыки оценки собственной речи, активизируется внимание студентов в ситуации профессионального общения.

Таким образом, ситуационная модель медицинского дискурса, представленная в видеоматериалах, может не только обеспечить потребность обучающихся в образце вербального и невербального поведения профессионала, но и способствовать формированию знаний, навыков и умений профессионально-ориентированной коммуникации, а также повышает мотивацию студентов к изучению русского языка.

\section{ЛИТЕРАТУРА}

1. Барменкова 0.И. Видеозанятия в системе обучения иностранной речи / О.И. Барменкова // Иностранные языки в школе. - 1999. - №3. - С. 20-25.

2. Вербах К. Хантер Д. Вовлекай и властвуй. Игровое мышление на службе бизнеса. - М.: «Манн, Иванов и Фербер», 2015. - 160 с.

3. Гальскова Н.Д., Гез Н.И. Теория обучения иностранным языкам: Лингводидактика и методика: учеб. пособие для студентов линг. ун-тов и фак. ин. яз. высш. пед. учеб. заведений. - 2-е изд., испр. - М.: Академия, 2008. - 336 с.

4. Евплова Е.В. Геймификация как средство повышения мотивации к обучению // Одинцовские чтения. М., 2013. - [Электронный ресурс]. URL: http:// evplova.ru/nauchnye-i-metodicheskie-stati/53-gejmifikatsiya-kak-sredstvo-povysheniya-motivatsii-k-obucheniya (дата обращения: 12.01.2021).

5. Молочко Н.В. Видео в обучении русскому языку как иностранному. // Научные труды БГЭу. Юбилейный выпуск: Т.1. М.: БГЭУ, 2003. С. 823-832.

6. Толстова Н.Н. Пример использования короткометражных фильмов на занятиях по русскому языку как иностранному // Молодой ученый, 2017 . № 11. C. $493-497$.

7. Фролова А.М. Методика создания «Мобильного видео» при изучении русского языка как иностранного // Беларусь - Индия - Россия: сотрудничество в области преподавания русского языка как иностранного: Материалы интернет-конф., 13 ноября 2018 г. - с.249-252.

8. Kapp K. The Gamification of Learning and Instruction. John Wiley \& Sons, 2012.

9. Werbach K. Gamification // Coursera. URL: [https://class.coursera.org/gamification-002/lecture] (дата обращения: 12.01.2021).

(с Тележко Ирина Владиленовна (Irina-Telezhko@mail.ru), Яхно Мария Дмитриевна (mariayahno@mail.ru) Журнал «Современная наука: актуальные проблемы теории и практики» 